\title{
ІНСТИТУЦІЙНЕ ЗАБЕЗПЕЧЕННЯ БЮДЖЕТНОЇ ПОЛІТИКИ РОЗВИТКУ ТЕРИТОРІЙ
}

\author{
Пелехатий Андрій Олегович \\ кандидат економічних наук \\ Львівський національний університет імені Івана Франка (м. Львів, Україна) \\ ORSID: 0000-0002-3022-852X \\ Pelechatyj_a@i.ua
}

У статті досліджено особливості формування інституційних механізмів забезпечення бюджетної політики розвитку територій в Україні. Дано визначення бюджетної політики розвитку територій зі сторони інституційного підходу. Розглянуто інтерпретацію основних законів інституційної архітектоніки бюджетного процесу, а саме: закони рівноваги, усереднювання та структуризації. Представлено модель інституційної архітектоніки розвитку територій як системи, що розвивається, і опорними елементами якої виступають інститути та інституції. Досліджено основні складові інституційної архітектоніки бюджетної політики розвитку територій: система інститутів, інституиійно-правове забезпечення, інституційно-організаційне забезпечення, адаптивні інструменти реалізації бюджетної політики. Визначено інституційні пріоритети бюджетної політики в межах визначених інституційних рівнів (Перший і найабстрактніший рівень пов'язаний з процесом "модернізації згори", коли держава визначає вектор соціально-економічного розвитку: Другим рівнем $\epsilon$ "модернізація знизу", що передбачає активізацію базових і похідних інститутів).

Ключові слова: бюджетна політика, розвиток територій, інституційна архітектоніка, інститути, інституційне забезпечення.

DOI: https://doi.org/10.32845/bsnau.2019.4.4

Постановка проблеми. Дослідження бюджетної політики розвитку територій на основі застосування інституційного підходу потребує ретельного вивчення ії інституційного забезпечення, особливо в умовах процесів фінансової децентралізації, адже сучасна економічна ситуація в Україні демонструє, що одним із найвпливовіших чинників, який відчутно гальмує розвиток країни, є інституційні деформації. Глибина сучасних проблем в економіці України потребує належного переосмислення сутності і значення бюджетної політики як на рівні держави загалом, так і в розрізі адміністративних територій, що й зумовлює необхідність запровадження упорядкованості механізмів функціонування відповідних інститутів та інституцій. Проголошена урядом наприкінці 2014 року реформа бюджетної системи, спрямована на децентралізацію бюджетних коштів, розподіл видаткових повноважень між рівнями публічної влади, джерел їх фінансування та забезпечення фінансової стійкості місцевих бюджетів - це важливий крок до створення необхідних умов для децентралізації влади з одночасним забезпеченням європейських стандартів адміністративної та фінансової незалежності органів місцевого самоврядування.

Аналіз останніх досліджень та публікацій. Вивчення змісту суспільних фінансів на основі методології̈нституціоналізму досліджувало зарубіжних вчених, а саме: Д. Норт, У. Нордхауз, П. Самуельсон , Дж. Стігліц та ін. Серед вітчизняних вчених дослідженням інституційних засад розвитку бюджетної політики займалися А. Гриценко та І. Чугунов, які стали засновниками наукової течії під назвою інституційна архітектоніка. Однак ряд процесів і на сьогодні залишається не відображеним, на що звертається увага у даній статті.

Метою статті $є$ дослідження інституційного забезпечення бюджетної політики розвитку територій.

Виклад основного матеріалу. Сьогодні, як і у попередні роки, питання інституціоналізації бюджетної політики в Україні характеризується актуальністю, а також посиленою увагою в контексті децентралізаційних процесів. Відтак існує потреба поглибленого дослідження особливостей формування інституційних механізмів забезпечення бюджетної

політики розвитку територій в Україні.

Зі сторони інституційного підходу, бюджетна політика розвитку територій - це складна політико-правова і організаційно-економічна система, до якої входять: сукупність суб'єктів державної, регіональної та місцевої влади, інститути громадянського суспільства, органи бюджетного регулювання, ОТГ, громадські організації, розпорядники бюджетних коштів та інші зацікавлені суб'єкти, які здійснюють непрямий вплив на характер і спрямованість бюджетної політики; сукупність об'єктів бюджетної політики (відносини, пов'язані з формуванням, розподілом та використанням бюджетних ресурсів територій); сукупність інструментів влади (політичних, економічних), які можуть бути використані для підтримки належного прийняття рішень у сфері бюджетної політики; масив чинних законодавчих і нормативно-правових документів, який визначає пріоритети бюджетної політики розвитку територій; офіційні погляди стосовно принципів та механізмів, а також підходів до ії̈ формування і реалізації та ін.

Використовуючи інструментарій інституціональної теорії, слід зауважити, що бюджет, і політика розглядаються як інститути, які орієнтований на результат і передбачають: правила, які регламентують зв'язок між бюджетуванням, ефективністю і результативністю виконавців; механізм примусу до виконання правил, які відповідають цій системі; механізм еволюційного розвитку (вдосконалення) бюджетної політики; здатність бюджетної політики сприяти фінансовій стабільності і соціально-економічному розвитку як держави загалом, так і її окремих територій, а також зниженню соціальної напруги і підтримці належного рівня життя громадян.

Таким чином, використання інституційного підходу до бюджетної політики розвитку територій вимагає дослідження системи норм, правил та законів, особливостей діяльності та взаємодії органів законодавчої, виконавчої влади, інших установ та визначення їх оптимального поєднання в контексті забезпечення соціально-економічного розвитку держави. В рамках дослідження до питання формування і розвитку інституційних механізмів бюджетної політики варто підходити як до динамічної системи, що змінюється в процесі постійного 
розвитку та адаптується до особливостей кожного окремого етапу соціально-економічного поступу держави. На нашу думку, інституційне забезпечення бюджетної політики розвитку територій розглядати з позицій сукупності основоположних інституцій, що визначають поведінку учасників бюджетного процесу, характер якої безпосередньо впливає на бюджетну політику розвитку територій, та інститутів, які мають забезпечити функціонування інституцій у процесах її формування та реалізації.

На думку І. Чугунова [1], з метою підвищення якісного рівня функціонування системи бюджетного регулювання доцільним є використання архітектоніки як особливої науки, що досліджує загальні принципи побудови цілісних систем, у тому числі інституційних. Використовуючи інституційний підхід до дослідження бюджетної системи та бюджетного регулювання, науковець зазначає, що інституційна архітектоніка бюджетної політики в системі державного регулювання включає систему правил, норм, законів, органів законодавчої й виконавчої влади, установ та їх оптимальне поєднання і співвідношення, за допомогою яких формуються та реалізуються стратегічні й тактичні цілі, спрямовані на забезпечення ефективного функціонування системи бюджетного регулювання та соціально-економічного розвитку країни. Досліджуючи інституційні аспекти бюджетної політики, Л. Лисяк характеризує інституційну архітектоніку бюджетної політики як динамічну систему, здатну постійно розвиватися та адаптуватися до особливостей певного етапу розвитку суспільства, його економічної, політичної, соціальної систем.

За підходами, розробленими професором А. Гриценком [2], інституційна архітектоніка є структурою інститутів, яку складають правила, норми, стереотипи, традиції, установи та інші соціальні утворення в їх співвідношеннях з суттю і загальним естетичним планом побудови цілісної соціальної системи. У цьому визначенні відображені об'єктивні, внутрішньо властиві системі відносини, значення суб'єктів у перетворюючої діяльності та необхідність її побудови згідно з внутрішніми закономірностям системи.

Враховуючи викладені вище міркування, інституційну архітектоніку бюджетної політики слід розглядати як сукупність певних інститутів та інституцій, які відображають стійкі, адекватні існуючому суспільному ладу, зв'язки між його підсистемами (стадіями).

У працях Т. Бугай [3] представлено інтерпретацію основних законів інституційної архітектоніки бюджетного процесу, до яких, зокрема, можна віднести закони рівноваги, усереднювання та структуризації.

Змістовна сутність закону рівноваги полягає в тому, що усі елементи бюджетної політики рухаються в напрямку спокою відносно інших елементів чи перебувають в цьому стані. Реалізація цього закону чітко простежується в процесі формування бюджетної рівноваги, яка означає, що бюджетні видатки покриваються бюджетними доходами. У випадку перевищення видатків над доходами виникає бюджетний дефріцит, тобто у цьому випадку рівновага порушується. Стан бюджетної рівноваги не означає тільки рівновагу в арифметичному розумінні, а й у випадку бюджетного профріциту, бюджет перебуває у стані рівноваги. Тому формування збалансованого бюджету на різних рівнях публічного управління залишається однією з ключових проблем функціонування бюджетної політики.
Закон усереднювання є більш конкретною формою дії закону рівноваги та дає просторову і кількісну характеристику взаємодії однорідних елементів цілісної системи, які перебувають в постійному русі. Якщо рівновага сама по собі не містить просторових характеристик і фіксує лише рівність значень, то усереднювання за своєю суттю $є$ просторовим і кількісним поняттям. Інституційна архітектоніка бюджетної політики як держави, так і розвитку територій, аналогічно формується за середньозваженими параметрами, які визначаються необхідними (середніми) значеннями суспільного розвитку.

Закон структуризації - третій закон інституційної архітектоніки бюджетної політики розвитку територій, який характеризує взаємозв'язок елементів, що мають внутрішні фактори розвитку і здатні об'єднуватися в певні цілісні утворення в межах більш широкої цілісності. Дія закону структуризації на практиці означає впорядкування бюджетних інституцій, їх взаємозв'язку з метою досягнення найкращих параметрів бюджетної політики розвитку територій в межах відповідного інституційно-організаційного та інституційноправового забезпечення.

На основі викладеного вище представимо модель інституційної архітектоніки розвитку територій як системи, що розвивається, і опорними елементами якої виступають інститути та інституції (рис. 1).

Інституційне забезпечення формується на рівні держави, регіону, міста, району, територіальної громади як представницька структура органів влади та управління. Ї̈ представляють також організаційні структури бізнесу, громадські організації, а також окремі громадяни (споживачі, постачальники ресурсів). Велике значення мають форми і способи їх впливу на економічні процеси. Сьогодні їх інституції тісно переплітаються, розвивається партнерство держави, бізнесу, громадянського суспільства.

Першою складовою інституційної архітектоніки бюджетної політики розвитку територій є система інститутів, під якими представник "нового" інституціоналізму Д. Норт розуміє традиції, звичаї (неформальні норми) та закріплені у праві правила і норми (формальні правила і норми), що створюють рамкові обмеження функціонування певного типу економічної системи, її суб'єктів, моделі їх поведінки. Іншими словами, науковець розглядає інститути з позицій формальних правил, неформальних обмежень і механізмів їх примусового виконання.

На думку С. Онищенко [4], у сфері бюджетних відносин функціонують такі інститути: політико-правові інститути, пов'язані із забезпеченням громадянських і політичних прав громадян та економічних агентів, а також покликані сприяти ефективній взаємодії громадянського суспільства і правової держави; законодавчі інститути, які формують нормативноправове й законодавче поле для економічного зростання і структурної модернізації економіки держави; соціальні інститути включають інститути, пов'язані із забезпеченням соціального, морально-етичного, психофізіологічного зростання людини в суспільстві. До таких важливих державних інститутів, передусім, слід віднести: освіту, охорону здоров'я, пенсійну систему тощо; економічні інститути які, власне, створюють передумови для економічного зростання держави та беруть безпосередню участь у структуризації бюджетного процесу (державне фінансування, оподаткування, митне регулювання тощо). 


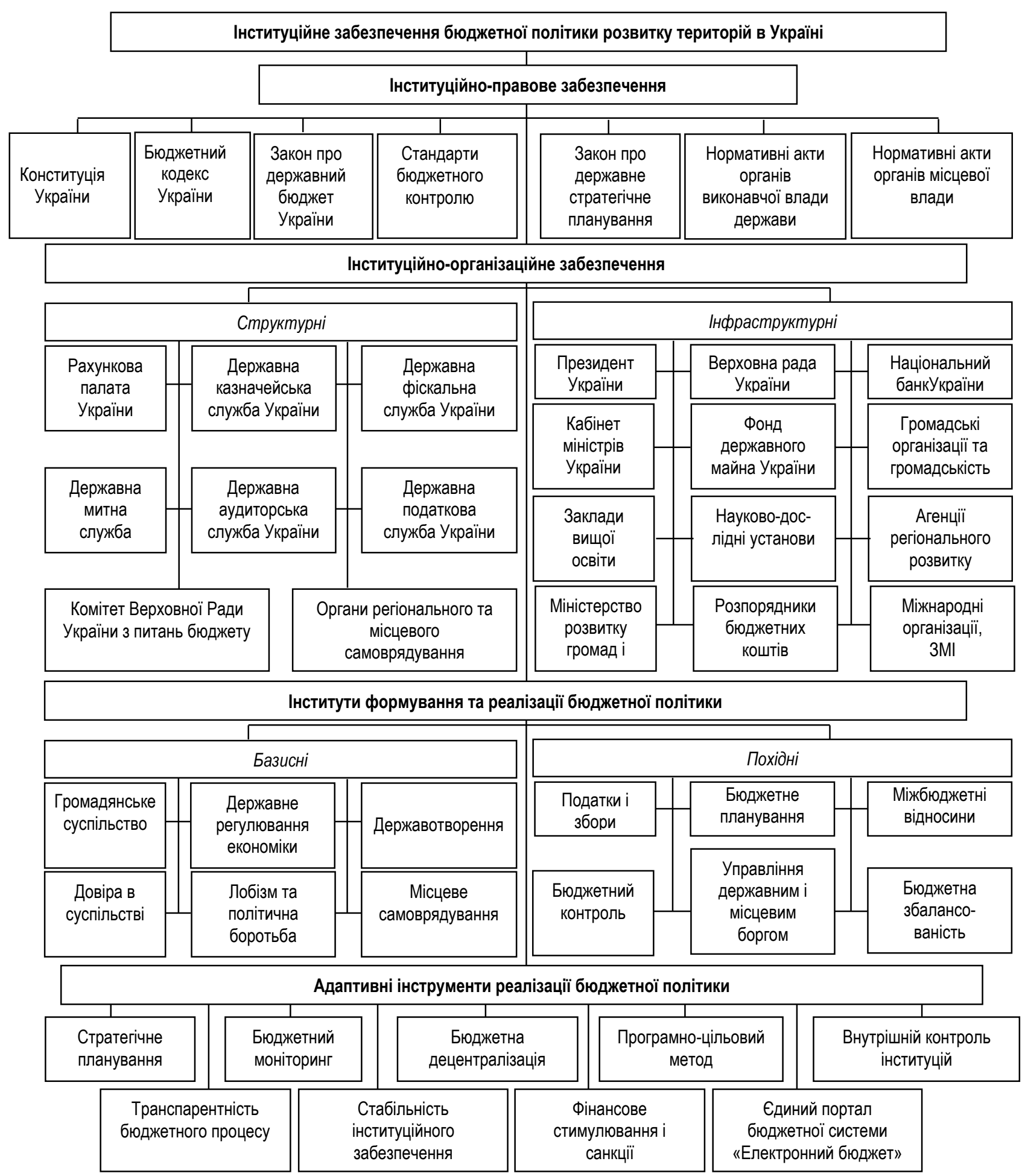

Рис. 1. Модель інституційної архітектоніки бюджетної політики розвитку територій в Україні

Бюджетна політика розвитку територій $є$ невіддільною від існуючих у країні та на територіальному рівні інститутів, які утворюють певне інституційне середовище, що визначає відповідні фінансові відносини, які виникають внаслідок діяльності держави, місцевих органів влади й суб'єктів ринкового механізму. Держава і місцеві органи влади, спрямовуючи діяльність на вдосконалення базових інститутів економічного розвитку (власності, управління, праці), тим самим вибудовують підгрунтя для формування й реалізації ефективної бюджетної політики.
У поданій вище авторській моделі інституційної архітектоніки бюджетної політики розвитку територій в Україні зазначено базисні і похідні інститути.

Базисні інститути в структурі інституційного забезпечення бюджетної політики розвитку територій відображають сформовані в державі та на рівні окремих територій суспільно-економічні, політичні відносини, норми, стандарти розвитку, регламенти, які неминуче призводять до системних змін у структурі бюджетних відносин [5].

На основі базисних вибудовуються похідні інститути 
бюджетного процесу: оподаткування, управління державним і місцевим боргом, міжбюджетних відносин, бюджетного планування, бюджетного контролю, бюджетної збалансованості тощо.

Функціонування суспільних інститутів істотною мірою визначається системою неформальних чинників (звичаї, традиції, кодекси, норми поведінки, культурні цінності), які пояснюють специфіку інституціональної структури конкретного суспільства. з боку зовнішнього середовища можливі різноманітні впливи на ефективність функціонування економічних систем. Ці зміни примушують суспільство постійно впроваджувати пошук нових дієвих суспільних інститутів.

Наступною складовою інституційної архітектоніки бюджетної політики розвитку територій є її інституиійноправове забезпечення, яке проявляється як сукупність формальних інституційних обмежень, що регулюють діяльність структурних та інфраструктурних інституцій. Така діяльність спрямована на здійснення комплексу заходів з організації, взаємодії, інформування, контролю й моніторингу, а також інших фрункціонально-розпорядчих дій 3 метою підвищення здатності бюджетної політики забезпечити платоспроможність й фінансову стійкість як держави, так і на рівні окремих територій, ефективне використання бюджетних коштів у процесі виконання функцій органами державної і місцевої влади з урахуванням стратегічних пріоритетів розвитку бюджетних відносин [6].

До нормативно-правових актів, що регулюють процеси формування бюджетної політики в Україні, належать: Конституція України, Бюджетний кодекс України, Закон України "Про Державний бюджет України на поточний рік", нормативно-правові акти центральних органів виконавчої влади, інші закони, що регулюють бюджетні правовідносини, нормативно-правові акти Кабінету Міністрів України, рішення про місцевий бюджет.

Необхідною умовою формування виваженої бюджетної політики розвитку територій її ефективної реалізації є наявність цілісної, стабільної і зрозумілої інституційно-правової бази. У такому контексті важливо вдосконалити інституційноправове забезпечення бюджетної політики в частині щодо ув'язки бюджету зі стратегією і пріоритетами соціально-економічного розвитку як на рівні держави, так і на рівні окремих територій.

Інституційно-правове забезпечення бюджетної політики розвитку територій надає цілеспрямованості, послідовності, структурованості діяльності бюджетних інституцій, визначає ефективні напрями такої діяльності, особливості їх застосування на різних стадіях процесу формування і використання фінансових ресурсів. Отже, правова форма не тільки юридично фіксує статус різноманітних органів у системі забезпечення реалізації певної функції механізму регулювання бюджетних відносин, а й визначає форми реалізації ними вимог чинного законодавства і координатора реалізації правових ідей.

Одним 3 невід'ємних елементів структури інституційного забезпечення бюджетної політики розвитку територій $€$ інституційно-організаційне забезпечення.

Інституції в бюджетній політиці розвитку територій $€$ чітко структурованими формуваннями, які є суб'єктами бюджетних відносин, які мають відповідне організаційне та нормативно-правове забезпечення, а їх діяльність спрямована на регламентацію та безпосереднє здійснення планування і використання коштів місцевих бюджетів і реалізується через складання, розгляду, затвердження, виконання бюджетів, звітування про їх виконання, а також контролю за цими процесами. Вони забезпечують ефективне використання коштів Державного та місцевих бюджетів і діють відповідно до закріпленого в інституційно-правовому полі регламенту дій щодо раціонального перерозподілу бюджетних ресурсів для досягнення поставлених цілей. У авторській моделі інституційної архітектоніки бюджетної політики розвитку територій вони поділені на структурних та інфраструктурних інституцій. Структурні інституції представлені тими учасниками, які створюються в законодавчому порядку і наділяються правами регулятивного впливу виключно в бюджетній сфері. Тобто без існування інституту бюджету в державі діяльність таких інституцій втрачає сенс. Інфраструктурні інституції бюджетного процесу в Україні мають виконувати окремі, законодавчо врегульовані функції на різних стадіях реалізації бюджетного процесу, сприяючи тим самим формуванню та ефективній реалізації бюджетної політики $[7,8]$.

Інфраструктурні інституції які безпосередньо беруть участь в організації та реалізації стадій складання, розгляду, затвердження, виконання, звітування про виконання бюджетів і контролю за використанням бюджетних коштів, але це не $€$ основною функцією цих інституцій. Вони виконують окремі, законодавчо врегульовані функції на різних стадіях формування і реалізації бюджетної політики.

Найвищим інституційним органом у питаннях організації бюджетного процесу є Верховна Рада України. Ї̈̈ інституційна роль є провідною на всіх стадіях бюджетного процесу, оскільки ця інституція здійснює: визначення основних напрямів бюджетної політики на наступний рік; ухвалення постанов про основні напрями бюджетної політики держави; розгляду та ухвалення показників соціально-економічного розвитку країни, які необхідні для формування бюджетів усіх рівнів (проект закону про Державний бюджет України); розгляд й затвердження законопроектів, що дозволяють коригувати дохідну і видаткову частини бюджетів; заслуховування звітів про виконання Державного бюджету України (включаючи звіти головних розпорядників коштів державного бюджету про використання ними бюджетних коштів та результати виконання відповідних бюджетних програм); розгляд та затвердження річного звіту про виконання бюджету; використання кредитів (позик), що залучаються державою від іноземних держав, банків і міжнародних фінансових організацій.

До інфраструктурних інституцій реалізації бюджетної політики на місцевому рівні належать обласним, районним, сільським, селищним, міським і районним радам. У свою чергу, ці інституції наділені бюджетними повноваженнями в частині розгляду та затвердження бюджетів відповідного рівня; розгляду і затвердження звітів про їх виконання, а також контролю.

Комітет Верховної ради з питань бюджету приймає рішення щодо бюджетних законопроектів, узагальнює висновки інших комітетів щодо Закону про державний бюджет, заслуховує інформацію щодо виконання бюджетних повноважень на всіх стадіях бюджетного процесу.

Виключна інституційна роль у бюджетному процесі належить Кабінету Міністрів України і визначається п. 1 ст. 32 
БКУ, де зазначено, що саме уряд розробляє проект Закону "Про Державний бюджет України". Кабінет Міністрів України розробляє, схвалює і подає Верховній Раді України основні прогнозні макроекономічні показники соціально-економічного розвитку України, проект Основних напрямів бюджетної політики, проект закону про Державний бюджет України та звіт про виконання Державного бюджету України; забезпечує виконання закону про Державний бюджет України; розраховує показники зведеного бюджету України і готує звіт про його виконання; формує інформацію щодо прийнятих законодавчих і нормативних актів на виконання закону про Державний бюджет України; приймає рішення щодо виконання закону про Державний бюджет України; приймає рішення стосовно використання резервного фонду Державного бюджету України; приймає рішення про здійснення запозичень в обсягах і на умовах, визначених законом про Державний бюджет України.

Ключовою інсрраструктурною інституцією, яка несе відповідальність за складання проекту закону про Державний бюджет України, визначає основні організаційно-методичні засади бюджетного планування, що використовуються для підготовки бюджетних запитів і розроблення проекту Державного бюджету України та прогнозу Державного бюджету України на наступні за плановим два бюджетні періоди, $є$ Міністерство фрінансів України.

Інституційна роль Національного банку України в реалізації бюджетного процесу виявляється на стадії складання проекту Державного бюджету України. НБУ, як інфраструктурна інституція, виконує інформаційно-аналітичні функції, серед яких слід виділити такі: визначає основні принципи грошово-кредитної політики України, готує пропозиції до проекту закону про державний бюджет.

Важливою інфраструктурною інституцією, яка здійснює непрямий вурдив на процеси формування та реалізації бюджетної політики розвитку територій є Міністерство розвитку громад та територій України (Мінрегіон).

Ще однією інфраструктурною інституцією є Фонд державного майна України. Він $€ €$ центральним органом виконавчої влади із спеціальним статусом, що реалізує державну політику у сфері приватизації, оренди, використання та відчуження державного майна, управління об'єктами державної власності, у тому числі корпоративними правами держави щодо об'єктів державної власності, що належать до сфери його управління.

До інфраструктурних учасників інституційно-організаційного забезпечення формування та реалізації бюджетної політики розвитку територій належать громадськість та громадські організації.

Іншими інфраструктурними інституціями у сфрері бюджетної політики розвитку територій $є$ засоби масової інформації, науково-дослідні установи та заклади вищої освіти та розпорядники бюджетних коштів.

Що стосується структурних інституцій, то на стадії контролю, підготовки та розгляду звіту про виконання бюджету і прийняття рішення щодо нього визначальною $є$ роль Рахункової палати України, яка $€$ постійно діючим органом зовнішнього державного фінансового контролю.

Ефективне управління ресурсами єдиного казначейського рахунку для своєчасного та в повному обсязі виконання видаткової частини бюджету - це стратегічна місія діяльності Державної казначейської служби України.
Повноваження контролю за бюджетними ресурсами покладено на Державну аудиторську службу України. Ця інституція наділена повноваженнями в частині контролю за цільовим, ефективним використанням і збереженням державних фінансових ресурсів; досягненням економії бюджетних коштів і результативності в діяльності розпорядників бюджетних коштів; цільовим використанням і своєчасним поверненням кредитів (позик), отриманих під державні (місцеві) гарантії; достовірністю визначення потреби в бюджетних коштах під час складання планових бюджетних показників та відповідністю взятих розпорядниками бюджетних коштів бюджетних зобов'язань.

Формування інституційного забезпечення бюджетної політики розвитку територій передбачає, що базисні і похідні інститути, а також структурні та інфраструктурні інституції діють у межах інституційно-правового поля, здійснюючи свій вплив через адаптивні інструменти бюджетної політики розвитку територій, які будуть розглянуті нами у наступному підрозділі дисертаційної роботи.

Як показують наші дослідження, інституційне забезпечення бюджетної політики розвитку територій охоплює вихідні, базові, суттєві зв'язки між елементами інституційно-організаційними інституціями. Це забезпечення формується за наявності чітко визначеного набору об'єктивних бюджетних відносин, на які, у свою чергу, впливають домінуючі в суспільстві інститути. Це означає, що пріоритетами і напрямам розвитку територій на основі бюджетної політики, відповідають ті чи інші складові інституційного забезпечення, зумовлені політичними й економічними інтересами.

Ефективний розвиток територій в державі на базі формування та реалізації бюджетної політики залежить від належного інституційного забезпечення та поетапного виконання визначених завдань. Для цього необхідно чітко визначити інституційні пріоритети бюджетної політики в межах визначених інституційних рівнів. Перший і найабстрактніший рівень дослідження інституційного забезпечення бюджетної політики розвитку територій пов'язаний з процесом “модернізації згори", коли держава визначає вектор соціально-економічного розвитку. Другим рівнем є "модернізація знизу", що передбачає активізацію базових і похідних інститутів, а також структурних та інфраструктурних інституцій, зокрема й тих, які функціонують на територіальному рівні.

Що ж стосується першого рівня, формування ефективної бюджетної політики держави потребує виокремлення таких інституційних пріоритетів:

- спрямування економічних реформ в країні на підвищення рівня і якості життя населення, сприяння інноваційному розвитку та конкурентоспроможності економіки, стабілізації військово-політичної ситуації та економічному зростанню держави;

- модернізація податкового адміністрування для зниження витрат платників податків на дотримання вимог законодавства;

- підвищення інституційної спроможності державних контрольно-ревізійних органів у сфері бюджетних відносин;

- розвиток методології середньо- та довгострокового бюджетного планування, забезпечення ефективності планування та використання бюджетних коштів при реалізації секторальних реформ у сфері надання суспільних благ та послуг;

- імплементація провідного зарубіжного досвіду для 
гуманізації бюджетної системи та сприяння інтеграції України до глобальної системи розвитку;

- посилення інформаційної безпеки державних та місцевих фінансових органів;

- забезпечення прозорості (транспарентності) бюджетного процесу;

- забезпечення збалансованості бюджетів усіх рівнів.

Пріоритети бюджетної політики розвитку територій у розрізі другого рівня повинні відображати її реалізацію в розрізі таких складових:

1. Обгрунтування способів, методів та інструментарію інституційних змін у бюджетній політиці розвитку територій.

2. Визначення закономірностей та суперечностей інституційного забезпечення бюджетної політики розвитку територій та у розрізі діяльності окремих інституцій.

3. Вибір цілей удосконалення бюджетної політики розвитку територій та сприяння консолідації інтересів її стейкхолдерів.

4. Обгрунтування інструментів вдосконалення інституційної структури фінансового ринку.

5. Розроблення послідовності застосування інструментів вдосконалення бюджетної політики розвитку територій .

На підставі зазначеного вище нами визначено такі пріоритети бюджетної політики розвитку територій у розрізі другого рівня:

- забезпечення адекватного та ефективного розподілу бюджетних повноважень, ресурсів та відповідальності за прийняття та виконання зобов'язань між різними рівнями публічного управління;

- формування ефективної адміністративно та фінансово спроможної системи управління територіями;

- стимулювання та підтримка місцевих ініціатив щодо ефективного використання внутрішнього потенціалу регіонів для створення та підтримання повноцінного життєвого середовища, підвищення якості життя людей;
- організація ефективної структури фрінансових надходжень у місцеві бюджети, вирішення суперечностей між дохідною і видатковою частинами бюджетів;

- забезпечення самостійності місцевих бюджетів та їх фінансової автономії;

- законодавче забезпечення ефективного управління фінансовим наповненням доходів та використанням бюджетних ресурсів на рівні територій;

- укрупнення територіальних громад базового рівня та розширення повноважень органів місцевої влади, корегування системи функцій, які покладаються на територіальні громади;

- розширення фінансової бази територіальних громад шляхом передачі низки податків та зборів (чи їх частин) на місцевий рівень;

- створення чіткого та ефрективного механізму контролю та моніторингу використання бюджетних ресурсів на рівні територій.

Висновки. Таким чином, необхідною умовою інституційного забезпечення бюджетної політики розвитку територій $€$ інституційна стабільність, яка передбачає можливість її формування та реалізації бюджетних відносин і програм навіть в умовах негативних змін бюджетного законодавства, оподаткування тощо. Відтак розвиток інституційного забезпечення повинен відбуватися у напрямі утвердження відповідних механізмів, дія яких сприятиме мінімізації інституційних ризиків та створенню сприятливого інституційного середовища. Досягнення цієї стратегічної мети можливе лише за умови правильного вибору цілей розвитку у сфері інституційного забезпечення і сприяння консолідації інтересів усіх економічних агентів, зацікавлених у формуванні адекватної, ефективної та прозорої бюджетної політики розвитку територій.

\section{Список використаної літератури:}

1.Чугунов І. Я., Лисяк Л.В. Бюджетна система в інституційному середовищі суспільства. Фінанси України. 2009. № 11. C. $3-11$.

2.Гриценко А. А. Институциональная архитектоника: предмет, основные законы, методология / А. А. Гриценко : науч. труды Донец. нац. техн. ун-та. Вип. 103-1. Донецк, 2006. С. 31-37. (Серия: Экономическая)

3.Бугай Т. Система інституційного забезпечення бюджетного процесу в Україні. Вісник КНТЕУ. 2015. №2. С. 103-118

4.Онищенко С. Інституційне забезпечення бюджетної безпеки України. Вісник Київського національного університету імені Т. Шевченка. 2016. №5 (182). С. 31-38

5.Богма О.С. Інституалізація як інструмент забезпечення бюджетної безпеки країни. Науковий вісник Мукачівського державного університету. 2017. Вип. 1 (7). С. 193-197

6.Савастєєва О.М. Модель механізму функціонування інституційної архітектоніки бюджетного процесу на місцевому рівні. 2018. №3. С. 230-235

7.Пелехатий А.О. Бюджетна політика у забезпеченні розвитку територій: концептуальні домінанти та напрями модернізації: [монографрія] / А.О. Пелехатий. Львів: Львівський національний університет імені Івана Франка, 2019. - 386 с.

8.Пелехатий А.О. Обгрунтування нової парадигми бюджетної політики розвитку територій в умовах реформування публічних фінансів в Україні. Електронне наукове фахове видання «Ефективна економіка», №7, 2019 [Електронний ресурс]. Режим доступу: http://www.economy.nayka.com.ua/?op=1\&z=7191

\section{References:}

1.Chuhunov I. Ya., Lysiak L.V. (2009). Biudzhetna systema v instytutsiinomu seredovyshchi suspilstva [The budget system in the institutional environment of society]. Finansy Ukrainy- Finance of Ukraine. № 11. pp. 3-11. [in Ukrainian].

2. Hrytsenko A. A. (2006). Ynstytutsyonalnaia arkhytektonyka: predmet, osnovnыe zakonы, metodolohyia [Institutional architectonics: subject, basic laws, methodology]. nauch. trudb Donets. nats. tekhn. un-ta [scientific. works of Donets. nat. tech. un-that]. Vol. 103-1. Donetsk, pp. 31-37. (Seryia: Эkonomycheskaia) [in Ukrainian].

3.Buhai T. (2015). Systema instytutsiinoho zabezpechennia biudzhetnoho protsesu v Ukraini [System of institutional support 
of the budget process in Ukraine]. Visnyk KNTEU [KNTEU Bulletin]. Vol. 2. pp. 103-118 [in Ukrainian].

4. Onyshchenko S. (2016). Instytutsiine zabezpechennia biudzhetnoi bezpeky Ukrainy [Institutional Support for Budgetary Security of Ukraine]. Visnyk Kyivskoho natsionalnoho universytetu imeni T. Shevchenka [Bulletin of the T. Shevchenko National University of Kyiv.]. Vol. 5 (182). pp. 31-38[in Ukrainian].

5.Bohma O.S. (2017). Instytualizatsiia yak instrument zabezpechennia biudzhetnoi bezpeky krainy [Institutionalization as a tool for ensuring the budgetary security of the country]. Naukovyi visnyk Mukachivskoho derzhavnoho universytetu [Scientific Bulletin of Mukachevo State University]. Vol. 1 (7). pp. 193-197[in Ukrainian].

6.Savastieieva O.M. (2018). Model mekhanizmu funktsionuvannia instytutsiinoi arkhitektoniky biudzhetnoho protsesu na mistsevomu rivni [Model of mechanism of functioning of institutional architecture of budget process at local level]. 2018. №3. p. 230235. [in Ukrainian].

7.Pelekhatyi A.O. (2019). Biudzhetna polityka u zabezpechenni rozvytku terytorii: kontseptualni dominanty ta napriamy modernizatsii [Budget Policy in Territorial Development: Conceptual Dominants and Directions for Modernization]. Lviv: Lvivskyi natsionalnyi universytet imeni Ivana Franka, 386 p. [in Ukrainian].

8.Pelekhatyi A.O. Obhruntuvannia novoi paradyhmy biudzhetnoi polityky rozvytku terytorii v umovakh reformuvannia publichnykh finansiv $v$ Ukraini [Substantiation of the new paradigm of budgetary policy of territorial development in the context of public finance reform in Ukraine]. Efektyvna ekonomika - Effective Economics, №7. Retrieved from: http://www.economy.nayka.com.ua/?op=1\&z=7191. [in Ukrainian].

Pelekhatyy A., PhD, Ivan Franko National University of Lviv (Lviv, Ukraine)

Institutional support of budgetary policy for territorial development

The article investigates the peculiarities of the formation of institutional mechanisms for ensuring the budgetary policy of territorial development in Ukraine. The definition of the budgetary policy of territorial development from the side of the institutional approach. The interpretation of the basic laws of institutional architectonics of the budget process, namely: the laws of equilibrium, averaging and structuring, are considered. A model of institutional architectonics of territorial development as a developing system and supporting elements of which institutions and institutions act. The basic components of institutional architecture of the budget policy of territorial development are investigated: the system of institutions, institutional and legal support, institutional and organizational support, adaptive tools for budgetary policy implementation. The legislative acts regulating the processes of budgetary policy formation in Ukraine are presented: the Constitution of Ukraine, the Budget Code of Ukraine, the Law of Ukraine "On the State Budget of Ukraine for the current year", the normative legal acts of the central executive bodies, other laws regulating budgetary legal relations, regulations of the Cabinet of Ministers of Ukraine, local budget decision. Infrastructural institutions of budgetary policy implementation at different administrative and territorial levels are specified: President of Ukraine, Verkhovna Rada of Ukraine, Cabinet of Ministers of Ukraine, National Bank of Ukraine, State Property Fund, public organizations and public, research institutions, higher education institutions, regional development agencies, international organizations, the Ministry of Finance of Ukraine, the Ministry of Development of Communities and Territories of Ukraine, city, district, regional councils. Institutional priorities of budgetary policy within the defined institutional levels are defined (the first and most abstract level is related to the process of "top-down modernization" when the state defines the vector of socio-economic development: the second level is "bottom-up modernization", which implies the activation of basic and derivative institutions).

Key words: budget policy, territorial development, institutional architectonics, institutes, institutional support.

Дата надходження до редакції: 07.11.2019 p. 